\title{
The Skin's Neurological Function Evaluation in Post-Bariatric Plastic Surgery
}

\author{
Rodolpho Alberto Bussolaro • Elvio Bueno Garcia • \\ Maria Teresa Zanella $\cdot$ Lydia Masako Ferreira
}

Published online: 9 September 2011

(C) Springer Science+Business Media, LLC 2011

\section{Sir Rieger,}

With great enthusiasm we read your letter about our article [1] because we share the same points of view, considering questions about possible preservation of abdominal cutaneous sensation after post-bariatric abdominoplasties without flap undermining as previously studied [2]. The skin's neurological function refers directly to the sensorial function [3]. The conventional abdominosplasty causes hypoesthesia [4] that exposes the patients to traumas and accidental burn injuries [5].

Rieger et al. $[6,7]$ present a logical way (algorithm) to elect the most suitable technique for each formerly obese individual. One of the best clinical trials in post-bariatric plastic surgery that intended to find some possible causes of postoperative complications did not study the skin's neurological function [8].

It is well known that tegument's denervation damages the wound healing [9]. Future studies will investigate some possible correlation among skin's sensorial/neurological function and complications after post-bariatric plastic surgeries. Believing that tegument's neurological function should be maintained when possible, we keep studying and encouraging new researches about this subject.

R. A. Bussolaro $(\bowtie) \cdot$ E. B. Garcia $\cdot$ M. T. Zanella $\cdot$ L. M. Ferreira Universidade Federal de São Paulo,

São Paulo, SP, Brazil

e-mail: rodolphoab@uol.com.br

Conflicts of interest The authors declare that they have no conflicts of interest.

\section{References}

1. Bussolaro RA, Garcia EB, Zanella MT, et al. Impaired abdominal skin sensory function in morbid obesity and after bariatric surgery. Obes Surg. 2011. doi:10.1007/s11695-011-0485-Z

2. Bussolaro RA, Garcia EB, Barbosa MV, et al. Post-bariatric abdominoplasty: skin sensation evaluation. Obes Surg. 2010;20 (7):855-60. Epub 2008 Nov 4.

3. Weinstein S. Fifty years of somatosensory research: from the Semmes-Weinstein monofilaments to the Weinstein Enhanced Sensory Test. J Hand Ther. 1993;6(1):11-22.

4. Farah AB, Nahas FX, Ferreira LM, et al. Sensibility of the abdomen after abdominoplasty. Plast Reconstr Surg. 2004;114 (2):577-82.

5. Ozgenel Ege GY, Ozcan M. Heating-pad burn as a complication of abdominoplasty. Br J Plast Surg. 2003;56(1):52-3.

6. Rieger UM, Erba P, Kalbermatten DF, et al. An individualized approach to abdominoplasty in the presence of bilateral subcostal scars after open gastric bypass. Obes Surg. 2008;18(7):863-9. Epub 2008 Apr 3.

7. Rieger UM, Heider I, Bauer T, et al. Treatment algorithm for abdomino-torso body contouring in massive weight-loss patients in the presence of scars - a comprehensive review. J Plast Reconstr Aesthet Surg. 2011;64(5):563-72.

8. Coon D, Gusenoff JA, Kannan N, et al. Body mass and surgical complications in the postbariatric reconstructive patient: analysis of 511 cases. Ann Surg. 2009;249(3):397-401.

9. Barker AR, Rosson GD, Dellon AL. Wound healing in denervated tissue. Ann Plast Surg. 2006;57(3):339-42. 